\title{
Issues Surrounding the South China Sea Dispute
}

Motoyasu Nozawa

Faculty of Law, Graduate School of Law, Heisei International University, Saitama

Follow this and additional works at: https://gensoken.toyo.ac.jp/japanese-society-and-culture

Part of the Environmental Law Commons, International Law Commons, Legislation Commons, and the Organizations Law Commons

\section{Recommended Citation}

Nozawa, Motoyasu (2021) "Issues Surrounding the South China Sea Dispute," Japanese Society and Culture: Vol. 3 , Article 7.

DOI: $10.52882 / 2434-1738-0307$

Available at: https://gensoken.toyo.ac.jp/japanese-society-and-culture/vol3/iss1/7

This Article is brought to you for free and open access by Institute of Social Sciences. It has been accepted for inclusion in Japanese Society and Culture by an authorized editor of Institute of Social Sciences. 


\title{
Issues Surrounding the South China Sea Dispute*
}

Motoyasu Nozawa $* *$

\begin{abstract}
On 12 July 2016, the decision of the South China Sea Arbitration' ${ }^{1}$ (The Republic of the Philippines against the People's Republic of China) by a tribunal created under Annex XII to the United Nations Convention on the Law of the Sea was a near-complete victory for the Philippines. This arbitration concerned the role of historic rights and the source of maritime entitlements in the South China Sea, the status of certain maritime features and the maritime entitlements they are capable of generating, and the lawfulness of certain actions by China that were alleged by the Philippines to violate the Convention. In light of limitations on compulsory dispute settlement under the Convention, the Tribunal has emphasized that it does not rule on any question of sovereignty over land territory and does not delimit any boundary between the Parties.
\end{abstract}

Keywords: International Law, Arbitration, EEZ, UNCLOS, South China Sea

Introduction

The impetus for the dispute over the South China Sea originated in 1947 when the Republic of China officially drew the nine-dash line (the 11-dash line at the time) on a map for domestic use. The nine-dash line came to light in 2009 when China used the nine-dash line as a basis for asserting its sovereignty and sovereign rights over Malaysia and Viet Nam. In other words, this was the first time the nine-dash line was presented to foreign countries. Indonesia and the Philippines responded to this in 2011 . This led to the commencement of arbitration proceedings between the Philippines and China in 2013 under Annex VII to the United Nations Convention on the Law of the Sea (UNCLOS). As a result, on July 12, 2016, the arbitral tribunal almost fully accepted the Philippines' request, rejecting China's claims to the nine-dash line, the continental shelf, and title to the EEZ, finding China's actions illegal under international law. ${ }^{2}$ In

\footnotetext{
※ This article has been added to and modified from the one published in The Japanese Journal of Law and Political Science, Vol. 55, No. 1 by the Japanese Association of Law and Political Science.

※ Professor of International Law , Faculty of Law, Graduate School of Law, Heisei International University, Saitama Japan.

1 The South China Sea Arbitration (The Republic of Philippines v. The People's Republic of China), Award (12 July 2016), (hereinafter 'Award') (http://www:nansha.org.nc,Award) p. 75

2 http://www.pcases.com/web/view/7 The material in this case is from the above website. However, there are excellent prior studies on the historical background and jurisdiction of the South China Sea dispute. I have referred to the following materials as appropriate. Kentaro Nishimoto, "The Significance of South China Sea Arbitral Awards From the Perspective of International Law", Tohoku Law Review Vol. 4 (March 2017); Dai Tamada, "The Philippines v. China (United Nations Convention on the Law of the Sea, Annex VII Arbitration Court) Jurisdiction and Admissibility Ruling (October 29, 2015)”, Kobe Law Journal. Vol. 66, No. 2, September 2016; Yasuyuki Yoshida, "Case Studies: Philippines v. China: Arbitration over the South China Sea Issue (United Nations Convention on the Law of the Sea, Annex VII Arbitration Tribunal/Jurisdiction and Admissibility Rulings)”, Strategic Studies of the Maritime Academy, July 2016 (6-1).
} 
response, the Chinese government denied the jurisdiction of the court and argued that the ruling was simply "scrap paper", stating that the ruling was invalid and not legally binding.

This so-called "South China Sea Dispute" has been ruled on under the dispute settlement procedures of the UNCLOS. In Article 279, the UNCLOS stipulates that disputes concerning the interpretation and application of the UNCLOS shall be settled by peaceful means as stipulated in Article 33 of the UN Charter. Disputes that cannot be resolved by these peaceful means of resolution chosen by the parties to the dispute will be referred, at the request of any of the parties to the dispute, to a court of competent jurisdiction under the relevant provisions of the UNCLOS. In the present dispute, since neither the Philippines nor China had made a declaration under Article 287(1), the dispute was consequently referred to an arbitral tribunal under Annex VII to the UNCLOS. In short, because both countries were parties to the UN Convention on the Sea, they were ultimately subject to the compulsory jurisdiction of the relevant arbitral tribunal. ${ }^{4}$

This article examines the international legal implications of the arbitral tribunal for the Philippines and China, and what impact it will have on Japan.

\section{Background to Arbitral Tribunal and Claims of Both Countries}

The latest South China Sea dispute with neighboring countries became apparent in 2009 when China submitted an oral statement to the UN Secretary General in response to Malaysia and Vietnam's joint application to the Commission on the Limits of the Continental Shelf on the extension of the continental shelf. The content of the letter was that China has uncontested sovereignty over the islands in the South China Sea and adjacent waters, and sovereign rights over the relevant waters and the seabed and its submarine, and that the application seriously infringes on China's sovereignty and sovereign rights and jurisdiction in the South China Sea, while clarifying the nine-dash line. In response, Indonesia and the Philippines argued that China's claims were inconsistent with the UNCLOS and requested that the application not be considered. Such clashes between China and the countries surrounding the South China Sea have occurred frequently since 2010.

Therefore, on January 22, 2013, the Philippines initiated arbitration proceedings under Annex VII to the UNCLOS, based on Articles 286 and 287 of the UNCLOS, in order to find a solution to this problem. These proceedings, brought about by the Philippines, utilize the compulsory court system under the UNCLOS. As mentioned above, because both China and the Philippines are parties to the UNCLOS, jurisdiction was established, and furthermore, because neither country had made a declaration of choice of law, both countries were deemed to have accepted the arbitration proceedings as a result.

However, the dispute settlement procedure of the UNCLOS contains the following limitation of application provisions (Article 297) and selective exclusion provisions (Article 298), which narrow

\footnotetext{
3 According to the oral statement submitted by China to the UN Secretary General.

4 Under the United Nations Convention on the Law of the Sea, for the purpose of the settlement of disputes, the parties may, by declaration, (a) the International Tribunal for the Law of the Sea to be established by Annex VI, (b) the International Court of Justice to be established by Annex VI, (c) an arbitral tribunal to be established by Annex VII, (d) a tribunal organized by that Annex for one or more of the types of disputes provided for in Annex VIII If a party to a dispute that is not subject to the declaration in force at the time (paragraph 3 of Article 287) is a party to a dispute that is not subject to the declaration in force at the time (paragraph 3 of Article 287) and the parties to the dispute do not agree otherwise in relation to that dispute, the parties to the dispute shall be free to choose one or more of the measures of the special arbitration tribunal in force (Article 287(1)), as provided in Annex VII It is deemed to have accepted the arbitration process (paragraph 4).
} 
the jurisdiction of the dispute settlement procedure. That is, the mandatory procedure does not apply to disputes arising from the exercise of the rights granted to coastal states in relation to scientific investigation of the sea (Article 297(2) (a)) or disputes relating to the exercise of the sovereign rights of coastal states in the EEZ (Article 297(3) (a)). In addition, as already mentioned, it is permitted to declare in advance that disputes concerning the delimitation of maritime boundaries, disputes concerning "historic bays or historic title", disputes concerning "military activities" or "law enforcement activities", etc., are excluded from the mandatory procedure (Article 298). As will be discussed later, China has made all the exclusions it deems possible as early as 2006. Therefore, in the current South China Sea dispute, it cannot make any decisions about its territorial acquisition rights, including its territorial sovereignty and sovereign rights, or about its military activities.

Taking into account the above provision, and solely as a matter of interpretation and application of the UNCLOS, the Philippines filed the suit on the basis that a series of acts and claims by China violated the UNCLOS. Specifically, the title to the sea area in the South China Sea claimed by China is not based on the treaty; in other words, the claim of the nine-dash line is in violation of the UNCLOS; the landforms scattered in the South China Sea do not give rise to the title to the territorial sea, EEZ and continental shelf in light of the UNCLOS; and China's conduct in the South China Sea is an act that can be summarized as a violation of the obligation to protect the marine environment and prevent conflict deterioration under the UNCLOS, etc.

In response, China published the "Position Paper of the People's Republic of China on the Question of Jurisdiction of the South China Sea Arbitration Initiated by the Philippines" 5 on December 4, 2014 (available on its website), arguing that the arbitral tribunal does not have jurisdiction. The contents of the paper can be summarized in the following three points. First ${ }^{6}$, the main issue in the present arbitration proceedings is not outside the issue of territorial sovereignty over the topography of the South China Sea, and not the issue of interpretation and application of the UNCLOS. Secondly ${ }^{7}$, there is an agreement between China and the Philippines to resolve disputes between the two countries through negotiations in bilateral agreements and declarations on the conduct of the countries concerned in the South China Sea. The unilateral initiation of arbitration proceedings such as the present one is a violation of the Philippines' obligations under international law. Thirdly ${ }^{8}$, China had made a declaration in accordance with the Convention in 2006 excluding disputes regarding the demarcation of maritime boundaries from mandatory dispute settlement procedures, and even if the present issue concerned the interpretation and application of the Convention, it was still within the scope of this declaration.

The arbitral tribunal therefore considered the position paper and the letter later submitted by the Chinese Ambassador to the Netherlands to the respective judges as a preclusive defense and first heard the case on jurisdiction and admissibility. The Philippines prepared 15 allegations in its application for arbitration proceedings. In its review, the arbitral tribunal found jurisdiction over seven of the fifteen claims and reserved its decision on the remaining eight for the merits. With respect to the bilateral

5 Ministry of Foreign Affairs of the People's Republic of China, Position Paper of the Government of the Republic of China on the matter of Jurisdiction in the South China Sea Arbitration Initiated by the Republic of the Philippines (7 December 2014) (hereinafter Position Paper)

6 Position Paper paras. 1

7 ibid. paras. 2

8 ibid. paras. 3 
agreement with the Philippines asserted by China in its position paper, the Tribunal examined several treaties and statements to which the two countries were parties and found that it did not fall under either Article 281 or Article 282. Furthermore, the limitation of the applicability of Article 297 and China's 2006 declaration of exclusion from mandatory dispute settlement procedures in all matters permissible under Article 298 should be determined at the main drafting stage.

\section{Final Petition of the Philippines'}

The final allegations made by the Philippines involved 15 items $^{9}$. Allegations 1 and 2 sought a determination of the rights and title (historical title not based on treaties) in the waters of the South China Sea. Allegations 3 to 7 seek a determination of the status under international law of a particular landform in the South China Sea (i.e., the landform does not have an EEZ or continental shelf under the Convention). Allegations 8 to 14 are about the illegality of the acts being carried out by China in the South China Sea. Allegation 15 states that China should acknowledge that it has aggravated and expanded the dispute and cease its activities immediately.

Specifically (paras.99-105)

1 China's title to the South China Sea shall not exceed the scope of the title expressly permitted to be acquired by the UNCLOS.

2 China's assertions of sovereignty (i.e., rights), jurisdiction and historical rights in the waters enclosed by the so-called nine-dash line are invalid and in violation of the treaty if they exceed the limits of title allowed by the treaty.

3 Scarborough Shoal does not create title to the exclusive economic zone and continental shelf.

4 Mischief Reef, Second Thomas Reef and Subi Reef are low-tide uplands that do not create title to the territorial sea, the exclusive economic zone and the continental shelf and are not subject to acquisition by preoccupation or other territorial acquisition rights.

5 Mischief Reef and Second Thomas Reef are part of the Philippines' exclusive economic zone and continental shelf.

6 Gaven and McKennan Reefs (including Hughes Reef) are low-tide uplands that do not create title to the territorial sea, exclusive economic zone or continental shelf, but their low-tide line can be used to

\footnotetext{
9 In the Matter of an Arbitration before An Arbitral Tribunal Constituted under Annex VII to the 1982 United Nations Conventions on the Law of the Sea between the Republic the Philippines and the People Republic of China, Award on Jurisdiction and Admissibility (29 October 2015).

http://www.pcacases.com/web/view/7

In the introduction, the judgment on this matter stated the scope and scope of the arbitral tribunal, stating that the case was a case concerning the interpretive application of the United Nations Convention on the Law of the Sea (paras.8), that the nine-dash line was not in conformity with international law (paras.4), and in II, the circumstances leading to the arbitral award were described (paras.26-98), and In III, the 15-point Philippine motion was stated (paras.99-105). The following is a brief description of the following: IV is a matter of first instance (paras.106-129); $\mathrm{V}$ is a characterization of the location and nature of the dispute (paras.130-178); VI is the indispensability of the participation of third parties in the arbitration (paras.179-188); and VII is a prerequisite for the establishment of jurisdiction, which was an important point of view in the present case, Article 281 or Article 282 was considered for application to the South China Sea Declaration of Action (DOC), the China-Philippines Bilateral Statement, the Treaty of Friendship and Cooperation in Southeast Asia (TAC), the Convention on Biological Diversity (CBD), etc. (paras.189-353.) The automatic limitation on the jurisdiction of arbitral tribunals under Article 297 of the United Nations Convention on the Law of the Sea (UNCLOS) (paras.356-363), the selective exclusion from the jurisdiction of arbitral tribunals under Article 298 of the UNCLOS (paras.364-378.), and the preclusive nature of jurisdiction were considered and a final decision was made (paras.413.). On the question of jurisdiction, see above, pp. 29-54 in the Yoshida paper and pp. 126-138 in the Tamada paper.
} 
determine the baseline for measuring the territorial sea width of Namuiyet and Sincau Island.

7 Johnson's Reef, Cuateron Reef, and Fiery Cross Reef do not create an acquisition of authority over the exclusive economic zone and continental shelf.

8 China has illegally interfered with the sovereign rights enjoyed by the Philippines and the exercise of its sovereign rights over the biological and non-biological resources of the Philippines' exclusive economic zone and continental shelf.

9 China illegally failed to prevent the exploitation of biological resources by Chinese citizens and Chinese vessels in the Philippines' exclusive economic zone.

10 China interfered with the traditional fishing activities of Filipino fishermen at Scarborough Reef and illegally prevented Filipino fishermen from earning a living.

11 China has violated its obligations under the United Nations Convention on the Law of the Sea relating to the protection of the marine environment at Scarborough Reef, Second Thomas Reef, Cuateron Reef, Fiery Cross Reef, Gaven Reef, Johnson Reef, Hughes Reef and Subi Reef.

12 China's occupation and construction activities on Mischief Reef (a) violate the UNCLOS concerning artificial islands, facilities and structures; (b) violate its obligations under the UNCLOS concerning the protection and preservation of the marine environment (b) violates its obligations relating to the protection and conservation of the marine environment in the UNCLOS; and (c) constitutes an act of acquisition in violation of the UNCLOS.

13 China violated the UNCLOS by allowing its law enforcement vessels to operate in a dangerous manner that could cause a serious collision with Philippine vessels operating in the waters near Scarborough Reef.

14 Since the initiation of the arbitration proceedings in January 2013, China has illegally aggravated and escalated the dispute by the following acts. (a) interfering with the Philippines' right to navigate in Second Thomas Reef and surrounding waters; (b) interfering with the replacement of Filipino personnel stationed on Second Thomas Reef and the supply of them; (c) endangering the health and well-being of Filipino personnel stationed on Second Thomas Reef; (d) Dredging, creation and construction of artificial islands on Mischief Reef, Cuateron Reef, Fiery Cross Reef, Gaven Reef, Johnson Reef, Hughes Reef and Subi Reef.

15 China should cease further illegal claims and activities, respect the rights and freedoms of the Philippines under the UNCLOS article, comply with its treaty obligations, including those relating to the protection and preservation of the marine environment of the South China Sea, and give proper consideration to the treaty rights and freedoms of the Philippines in the South China Sea, and allow the Philippines to exercise its rights and freedoms.

In response to the application, the arbitral tribunal took into account the matters entrusted to it in the main proceedings and the position paper by China in arriving at the main proceedings.

III Decision on the merits and issues under international law

The arbitral tribunal rendered its plenary decision on the South China Sea dispute on 12 July, 2016. Below, I will examine the content of the decision in the order of the petition.

Although Petitions 1 and 2 related to China's title to the South China Sea, in particular the historical rights to the nine-dash line, the arbitral tribunal ultimately found jurisdiction over the claims and ruled that China's claims were not consistent with the UNCLOS. It held that the present rights claimed by 
China were in excess of 200 nautical miles from the treaty rights, i.e., the terrain over which China claimed its territorial rights, and therefore the basis for the title was exclusively based on historical rights ${ }^{10}$. However, the court held that historical rights were incompatible with China's previous claims (recognizing freedom of navigation and freedom of overflight in other countries) and were not recognized.

With regard to jurisdiction, it was held that China was only asserting a historical right that could not be called sovereignty, and did not reach "historical title," which is the assertion of sovereignty over the sea on the basis of so-called historical circumstances in Article 298. Hence, it was held that the present dispute was not subject to exclusion from mandatory dispute settlement procedures and that the jurisdiction of the arbitral tribunal was recognized.

With regard to the relationship between historical rights and the UNCLOS, it was held that there is no provision in the UN Convention on the Law of the Sea that permits the retention of historical rights to the exclusive economic zone and jurisdiction over the continental shelf, and that such rights are not consistent with the UNCLOS. Furthermore, the Tribunal held that in order for historical rights to be established, the historical acts must exceed the limits of the principle of freedom of the high seas and must have been tolerated by other countries for many years, and that China had enjoyed freedom of the high seas and consequently had engaged in navigation and fishing activities in the South China Sea. It explains that there is no clear evidence that the rights in question were acquired by historical title prior to the entry into force of the United Nations Convention on the Law of the Sea, and in particular, the ninedash line has even received protests, rather than tacit approval, from other countries.

Petitions 3-7 are about the status of the specific terrain that exists in the South China Sea. It is noteworthy here that the Court has defined terrain. That is, "naturally formed land, surrounded by water and still above the water's surface at high tide," as defined by Article 121(1), is generally considered a "high -tide feature" (i.e., a "rock"). High-tide features are defined as "those which are incapable of sustaining human habitation or independent economic life" (Article 121(3)). High-tide features that are not "rocks" are called "fully entitled islands" and they are considered to have the same title as other land (Article 121(2)) ${ }^{11}$.

So, with respect to the fourth and sixth petitions, the Philippines seeks a finding that the terrain given here is low-tide upland. There, the Court held that in order to be low-tide uplands, not to mention being above sea level at high tide, their status must be determined in their natural state and not dependent on man-made changes, and confirmed that low-tide uplands are not subject to possession on their own ${ }^{12}$. It also held that the status of being low-tide uplands must be certified by a variety of objective methods. In light of these criteria, it was held that Scarborough Reef, Cuateron Reef, Fiery Cross Reef, Johnson Reef, McKennan Reef and Gaven Reef (north), are high tide features, while Hughes Reef, Gaven Reef (south), Mischief Reef and Second Thomas Reef are lowtide uplands.

With respect to motions 3,5 , and 7 , we have attempted a comprehensive interpretation of Article

\footnotetext{
10 Award, paras.207-211. Nishimoto, supra note 23-24

With respect to the Senkaku Islands issue, China also claims territorial rights through historical title. Both of these claims are ill-founded, and in the event of a dispute by a court of law, they are unlikely to be considered problematic at all in relation to critical dates.

11 Ibid. paras 280

12 Ibid. paras539-551 Nishimoto, supra note 26, p.
} 
121 and, as noted above, Article 121 divides storm surge landforms into "islands of full authority" and "rocks" and attempts a detailed interpretation with respect to paragraph 3 of that Article. The status of the terrain is a capacity in its natural state, excluding extrinsic additions and modifications. Human habitation requires permanent habitation of the community. Independent economic life does not include dependence on external resources or mere mining activities. The ability of the terrain to be objectively assessed is essential for humans to lead their own economic life. As a result, it was concluded that all of the landforms listed in paragraphs 3 and 7 are rocks and do not create title to the exclusive economic zone and continental shelf. It was also held that in light of Article 121(3), none of the Itou Aba, Thitu Island, West York Island, Spratly Island, Southwest Cay and North East Cay had the capacity to sustain human habitation 13 .

As a result of these determinations, the Spratly Islands do not have a storm surge topography with an exclusive economic zone and continental shelf, and as a result, jurisdiction and the allegations regarding the Fifth Petition that Mischief Reef and Second Thomas Reef are part of the exclusive economic zone and continental shelf of the Philippines have been granted 14 .

Petitions 8-13 sought a finding that China's activities in the South China Sea not only violate the Philippines' exercise of sovereignty, but also violate its obligations under the UNCLOS (the duty to protect the marine environment).

By the previous granting of the motion, it was found that the subject sea area was the Philippine exclusive economic zone and the area comprising the continental shelf, and it was also found to be subject to the jurisdiction of the arbitral tribunal as it was not subject to the limitation and selective exclusion of mandatory dispute settlement procedures. As a result, many of China's activities that had been the subject of the Philippines' petition were found to be in violation of the United Nations Convention on the Law of the Sea.

Petition 14, concerning the aggravation or expansion of the dispute between the two countries, specifically refers to various Chinese activities on Second Thomas Reef and dredging and artificial islandbuilding activities in the Spratly Islands' terrain. In this regard, the court did not find jurisdiction over the latter, as it related to military activities and was subject to selective exclusion. On the other hand, the Court found jurisdiction over dredging activities and artificial island creation activities, as China denied that they were military activities. The Court then held that while a dispute arose and dispute settlement procedures were being taken, the parties had an obligation not only in the UNCLOS but also under general international law, not to aggravate or escalate the dispute, and that the irreparable aspects of the Mischief Reef, the irreparable damage caused to the marine environment, and the natural state of the terrain, was conduct that aggravated and expanded the dispute.

As to Allegation 15, we reject the Philippines' claim on the basis that its request is somewhat less clear and that the two countries do not aim to violate each other's rights.

IV Characteristics of the South China Sea Dispute Arbitration Tribunal

As I have already mentioned, this dispute has been referred to the dispute settlement procedure under Part 15 of the UNCLOS. Focusing on the fact that it was not referred to the International Court

13 Ibid. paras1169-1173 Nishimoto, supra note 36, p.

14 Ibid. paras.618-621 Nishimoto, supra note 28 
of Justice (ICJ), I would like to give an overview of the status of acceptance of dispute settlement procedures by the countries surrounding the South China Sea. It concerns nine countries: Japan, China, South Korea, the Philippines, Vietnam, Indonesia, Malaysia, Brunei, and Singapore15. The following is an overview of the status of acceptance of dispute settlement proceedings in the countries surrounding the South China Sea. First, only Japan and the Philippines (both with reservations) have deposited a declaration of acceptance of the Optional Clause of Article 36(2) of the Statute of the International Court of Justice. Neither country has made a declaration of procedure under Article 287 of the UNCLOS. With regard to the declaration of derogation from Article 298 of the Convention, China and the Republic of Korea have made all declarations in paragraphs (a), (b) and (c) of paragraph 1. Applying this situation to China and the Philippines, which are parties to the present dispute, the ICJ's declaration of acceptance of the Optional Clause cannot be automatically established because China has not deposited it. However, in the case of concluding a separate referral agreement with China, the possibility of China's response to the Philippines' unilateral complaint (Article 38(5) of the ICJ Statute) cannot be ruled out, but it is not very realistic. As to the choice of procedure under Article 287 of the UNCLOS, as neither State has done so, it is deemed to have accepted the referral of the dispute to an arbitral tribunal under Annex VII, pursuant to Article 287(3) of the Convention. With respect to the declaration of selective exclusion of Article 298 of the UNCLOS, China has declared all provisions of the Convention (a), (b) and (c) to be subject to selective exclusion, limiting the jurisdiction of the arbitral tribunal under Annex VII (subject matter jurisdiction). That is to say, it specifically excludes "boundary demarcation disputes" and "historical bays or historical title", as well as disputes concerning "military activities" and "disputes concerning law enforcement activities", so that, for example, the exclusive economic zone in the South China Sea and boundary disputes on the continental shelf are not subject to the jurisdiction of the arbitral tribunal in question. becomes.

In addition, jurisdiction is always limited with respect to certain matters by the limitation of application provision under Article 297. Furthermore, the UNCLOS is only a treaty on the law of the sea, which does not determine to which country a particular maritime topography belongs, and only "disputes relating to the interpretation or application of the Convention" (Article 286) are subject to trial. In this light, it is understandable that it would be extremely difficult to establish jurisdiction over events related to the South China Sea.

\section{Purpose of the Philippines}

Under these difficult circumstances, the Philippines has attempted to establish jurisdiction without losing its stance that this is a dispute concerning the interpretation and application of the UNCLOS, and it has succeeded in doing so. The results, as already mentioned, are detailed in the 15-point application submitted by the Philippines. Therein we can see a glimpse of the Philippines' skillful litigation prowess ${ }^{16}$. Specifically, whether China's claim to the so-called nine-dash line is permissible under the UNCLOS; whether the multiple maritime features in the waters of the South China Sea can give rise to their associated territorial waters, continental shelf, and exclusive economic zone; and whether China's conduct in the waters of the South China Sea is permissible under the UNCLOS (or in general the

15 Tamada, supra note 141

16 Tamada, supra note 142 , p. 
Philippines decided to dispute whether or not it was in violation of its obligations under international law), namely, the obligation to protect the marine environment and prevent the aggravation of disputes. In this way, the Philippines succeeded in establishing the jurisdiction of the arbitration tribunal.

However, despite the Philippines' success in establishing jurisdiction, I believe that the Philippines was well aware that even if it had won the arbitration case (indeed, the Philippines' arguments were almost entirely accepted), enforcement of the judgment would have been even more difficult.

I am not of the opinion that China will ever be expected to fully implement the ruling. If that is the case, why did the Philippines launch the arbitration trial this time? First of all, it was an attempt to make the South China Sea issue highly appealing to the international community and to win the support and endorsement of many countries in the international community. We can get a glimpse of the intention to advance diplomatic negotiations with China in the future by doing so. Secondly, the Tribunal attempted to resolve only a limited area of the case. Whether or not the nine-dash line is illegal under the treaty is undoubtedly a major issue in its own right, but the biggest issues in the South China Sea dispute are the territorial rights issue and the boundary demarcation issue. These have not been touched upon at all this time. However, the Philippines deserves full credit for taking a steady step forward in resolving these issues by narrowing the scope of the dispute and the issues at stake. In the long run, the decision cannot be seen as a minor issue for China.

\section{Effectiveness of the Judgment and China's Attitude}

China appears to have adopted a litigation strategy of not engaging as a litigant at all with respect to the arbitration proceedings. On December 7, 2014, one week before the commencement of the arbitral proceedings and the deadline set by the arbitral tribunal for China to submit its reply, the Chinese government dared to publish a position paper (published on its website) clarifying its position of denying the jurisdiction of the arbitral tribunal. Subsequently, through the Chinese Ambassador to the Netherlands, it sent a letter to the judge in charge of the arbitral tribunal, expressing its opposition to the arbitral proceedings and its objections. This was a way for their country to make its position clear by filing objections as appropriate in the course of the proceedings, although it would not be involved in the proceedings.

The position paper was simply published on the website 17 and was not submitted to the Arbitration Court, much less a formal "pre-determined defense". However, the arbitral tribunal considered it a "predetermined defense" and held a hearing on jurisdiction and admissibility. China did not consistently participate in the subsequent arbitration proceedings, which led to the so-called "trial in absentia". The UNCLOS provides that "the absence or failure of either party to the dispute to present a defense shall not impede the progress of the proceedings" (Article VII9 of the Annex), so the arbitral tribunal will proceed even if the litigant is absent. And as a result, a binding judgment was rendered.

China, as already mentioned, first denies the jurisdiction of the arbitral tribunal and argues that the judgment rendered as a result of that denial is also invalid. However, Article 296(1) of the UNCLOS first provides that "all parties to the dispute shall be subject to the tribunal having jurisdiction under the rules of this theory as final" and, in paragraph 2, "the tribunal referred to in paragraph 1 shall be binding between the parties to the dispute and only with respect to the dispute in question" and provides for the

17 See note 5 . 
individual effect of the dispute. In addition, in an arbitral tribunal, Article VII10 states in Annex VII10 that "the decision of the arbitral tribunal shall extend only to the matter that is the subject of the dispute" and Article XI provides that "the arbitral award shall not be allowed to be appealed as final, except in cases where the disputing parties agree in advance on the procedure for appeal. The parties to the dispute shall abide by such arbitral award". Since the basis for the binding effect stems from the fact that the parties are parties to the UNCLOS, China is naturally bound by the said decision insofar as it is also a party to the UNCLOS.

With respect to jurisdiction, the "court of competent jurisdiction" under Article 296 of the United Nations Convention on the Law of the Sea is also the final arbiter. As we have mentioned on many occasions, jurisdiction is a prerequisite for the court to have jurisdiction. The UN Convention on the Law of the Sea stipulates in Article 288(4) that "if there is a dispute as to whether or not a court has jurisdiction, it shall be decided by the tribunal of the court concerned," and the "power to determine jurisdiction" is to be determined by the court, not by the parties. China has argued at every turn that it does not have jurisdiction, but the 2015 review's determination that it does have jurisdiction (some of which were denied individually) makes China's argument legally inadmissible.

Despite binding judgments rendered in disputes by arbitral tribunals of competent jurisdiction, China has consistently rejected or ignored them. For example, Article 94 of the UN Charter promises that "cases in which a member of the UN Charter is a party shall be subject to the jurisdiction of the ICJ" (paragraph 1), and that if one party to a case is in default of a judgment, "the other party may appeal to the Security Council" and "the Council may, if it deems it necessary, recommend that the judgment be enforced and "may decide on the measures to be taken" (paragraph 2). Unfortunately, however, under the UNCLOS, there is no procedure to promote implementation or compel enforcement of a judgment by using the Security Council or other means to deal with non-performance of a judgment. However, it goes without saying that enforcement is not easy, even for the ICJ.

Conclusion Future Possibilities and Implications for Japan

The current South China Sea dispute is neither a territorial rights dispute nor a boundary demarcation dispute, but a title acquisition dispute. A title acquisition dispute refers to whether a particular maritime topography creates an acquisition of title to the EEZ, continental shelf, or territorial sea, or, more specifically in line with the present dispute, whether the area in question is an "island" or a "rock."

The dispute concerns the determination of whether the area is a "low-tide upland"18. With respect to this dispute, the jurisdiction of the arbitral tribunal was recognized because of the existence of a definition under the UNCLOS. In contrast, the UNCLOS did not provide for territorial disputes, and therefore jurisdiction was not recognized for territorial disputes. The boundary demarcation dispute fell under the category of selective exclusion and jurisdiction was not recognized. Viewed in this way, the question of acquisition of title was not a unilateral decision of a state or an agreement of the parties, but an objective one to be decided. And when it is determined (having a continental shelf or EEZ), it determines the high seas or deep-sea bed that exists beyond it (the sea floor). Unlike the interests of the states involved in boundary demarcation disputes, this is an important issue of intergenerational and common interest

18 Tamada, supra note 18, pp. 149-151 
that concerns not only the coastal states of the sea area concerned, but also all the states parties to the UNCLOS.

Finally, I would like to consider the potential impact of the court's decision on Japan. This case refers disputes to the dispute resolution process under Part 15 of the United Nations Convention on the Law of the Sea. The International Court of Justice (ICJ) is the primary forum for the resolution of disputes between nations. As mentioned above, the only way to establish the jurisdiction of the ICJ is to either deposit the Declaration of Acceptance of Optional Clause under Article 36(2) of the ICJ Statute, or to conclude a referral agreement between the countries at the time. As we have seen, most of the countries in East and Southeast Asia have not established ICJ jurisdiction. On the other hand, the dispute settlement procedures under Part 15 of the UNCLOS are narrower in jurisdiction, but any state party to the UNCLOS can still use the mandatory dispute settlement system. In particular, states that have not deposited the Optional Clause Trustee Declaration under Article 36(2) of the ICJ Statute are increasingly likely to use this procedure 19 .

This may pose a major problem for Japan as well regarding the issue of the legal status of Okinotorishima island. Although there is neither a territorial dispute nor a boundary demarcation dispute on Okinotori-shima island, the possibility of a title acquisition dispute has emerged. In the South China Sea dispute, the Philippines used China's argument that the Okinotori-shima island has neither an EEZ nor a continental shelf to elaborate on the characteristics of the title acquisition dispute. As a result, the court ruled that most of the landforms in the South China Sea claimed by the Philippines had neither an EEZ nor a continental shelf. For the same reason, it is conceivable that Okinotori-shima island could be found to be a "rock" with neither an EEZ nor a continental shelf. In that case, the dispute would be litigated using the UNCLOS dispute settlement process, not the ICJ. Who could guarantee that Japan would not be sued by China or South Korea as a defendant in this matter before the UNCLOS Annex VII Arbitration Tribunal? This matter therefore requires attention. $20 * * *$

\footnotetext{
19 Tamada, supra note 160

20 Tamada, supra note 161

*** This paper was supported by a 2020 Heisei International University Collaborative Research Grant.
} 